\title{
Hubungan Karakteristik Ibu dan Dukungan Suami dengan Tingkat Pengetahuan Ibu Hamil Tentang Tanda Bahaya Kehamilan
}

\author{
Vivi Budiart ${ }^{1 \star}$, Rismaina Putri ${ }^{1}$, Coryna Rizky Amelia ${ }^{1}$ \\ ${ }^{1}$ Program Studi S1 Kebidanan Fakultas Kedokteran Universitas Brawijaya \\ Email $^{*}$ : vivi.budiarti@gmail.com \\ HP : 085563493180
}

\begin{abstract}
One of the main indicators that can describe the condition of prosperous and healthy people in a country is to see the picture of the number of Maternal Mortality Rate (MMR). The high maternal mortality rate to date can be caused by complications of pregnancy that were previously marked by signs of distress during pregnancy. Dangers that appear in pregnancy is an early sign of a serious problem during pregnancy. The purpose of the current study is to know the relationship on the characteristics of mothers and support of husbands with the level of knowledge of pregnant women about the signs of pregnancy in BPM Sumidyah Ipung. In this research use research design in the form of observasional analitik with cross-sectional approach. The sample selected using quota sampling technique with the number of samples of 32 respondents. $P$ value $=0,037$ (education with knowledge level), $p$ value $=0,028$ (work with knowledge level), $p$ value $=0,049$ (parity test with knowledge level), $p$ value $=0,007$ (history of $A N C$ visit with knowledge level) and $p$ value $=0,007$ (husband support with knowledge level). Based on the analysis it can be concluded that there is a correlation between the age with the level of knowledge about the sign of pregnancy hazard, there is a correlation between education with the level of knowledge about the sign of pregnancy hazard, work with the level of knowledge about the sign of pregnancy hazard, there is relationship between parity with the level of knowledge about pregnancy alarm, there is an association between the ANC visit history and the knowledge level of pregnancy alarms, and there is a relationship between husband support and the knowledge level of pregnancy alarm.
\end{abstract}

Keywords: husband support, knowledge level, mother characteristics, pregnancy alarm

\begin{abstract}
ABSTRAK
Salah satu indikator utama yang dapat menggambarkan kondisi masyara-kat yang sejahtera dan sehat di suatu negara adalah dengan melihat gambaran jumlah Angka Kematian lbu (AKI). Angka kematian ibu yang tinggi sampai saat ini bisa disebabkan oleh adanya komplikasi kehamilan yang sebelumnya ditandai dengan adanya tanda bahaya pada masa kehamilan. Tanda bahaya yang muncul pada kehamilan tersebut merupakan pertanda awal adanya masalah yang serius pada
\end{abstract}


masa kehamilan. Tujuan dari penelitian yang dilakukan saat ini adalah mengetahui hubungan pada karakteristik ibu dan dukungan suami dengan tingkat pengetahuan ibu hamil tentang tanda bahaya kehamilan di BPM Sumidyah Ipung. Pada penelitian ini menggunakan desain penelitian berupa observasional analitik dengan pendekatan cross-sectional. Sampel yang dipilih menggunakan teknik quota sampling dengan jumlah sampel sebanyak 32 responden. Nilai $p$ value dari analisis statistik Chi Square test menunjukkan hasil $p$ value $=0,000$ (usia dengan tingkat pengetahuan), $p$ value $=0,037$ (pendidikan dengan tingkat pengetahuan), $p$ value $=0,028$ (pekerjaan dengan tingkat pengetahuan), $p$ value $=0,049$ (paritas dengan tingkat pengetahuan), $p$ value $=0,007$ (riwayat kunjungan $A N C$ dengan tingkat pengetahuan) dan $p$ value $=0,007$ (dukungan suami dengan tingkat pengetahuan). Berdasarkan analisis tersebut dapat disimpulkan bahwa ada hubungan antara usia dengan tingkat pengetahuan tentang tanda bahaya kehamilan, ada hubungan antara pendidikan dengan tingkat pengetahuan tentang tanda bahaya kehamilan, pekerjaan dengan tingkat pengetahuan tentang tanda bahaya kehamilan, ada hubungan antara paritas dengan tingkat pengetahuan tentang tanda bahaya kehamilan, ada hubungan antara riwayat kunjungan ANC dengan tingkat pengetahuan tentang tanda bahaya kehamilan, dan ada hubungan antara dukungan suami dengan tingkat pengetahuan tentang tanda bahaya kehamilan.

Kata kunci: dukungan suami, karakteristik ibu, tanda bahaya kehamilan, tingkat pengetahuan

*Korespondensi: Vivi Budiarti. Surel: vivi.budiarti@gmail.com 


\section{PENDAHULUAN}

Salah satu indikator utama yang dapat menggambarkan kondisi masya rakat yang sejahtera di suatu negara adalah dengan mellihat gambaran jumlah Angka Kematian lbu (AKI). Berdasarkan Survei Demografi dan Kesehatan Indonesia (SDKI) pada periode tahun 1991-2007, AKI mengalami penurunan dari 390 menjadi 228 per 100.000 kelahiran hidup. Namun pada SDKI 2012, AKI kembali naik menjadi 359 per 100.000 kelahiran hidup ${ }^{1,2}$.

Beberapa faktor dapat mening katkan terjadinya kematian pada ibu seperti adanya keterlambatan dalam mengetahui adanya tanda bahaya kehamilan yang merupakan suatu tanda adanya bahaya yang dapat terjadi selama kehamilan, keterlambatan untuk mencari pertolongan, keterlambatan datang ke fasilitas kesehatan dan keterlambatan memperoleh tindakan pertolongan kesehatan. Deteksi dini oleh tenaga kesehatan dan masyarakat tentang adanya faktor risiko dan kompli kasi serta penanganan yang adekuat sedini mungkin merupakan kunci keber hasilan dalam penurunan $\mathrm{AKI}^{3,4}$.

UU No.36 Tahun 2009 tentang Kesehatan mengamanatkan bahwa upaya kesehatan ibu ditujukan untuk menjaga kesehatan ibu sehingga mam pu melahirkan generasi yang sehat dan berkualitas serta mengurangi AKI. Upaya kesehatan ibu diwujudkan melalui pelayanan antenatal sekurangkurangnya 4 kali selama masa kehamilan. Standar waktu pelayanan tersebut dianjurkan untuk menjamin perlindungan terhadap ibu hamil dan atau janin, berupa deteksi dini faktor risiko, pencegahan dan penanganan dini komplikasi kehamilan ${ }^{5,6}$.

Kurangnya deteksi dini mengenali tanda bahaya kehamilan dan faktor risiko pada kehamilan dapat mengaki batkan kurangnya antisipasi yang cepat pada saat kehamilan sampai proses persalinan sehingga berisiko besar terjadinya kematian ibu. Tanda bahaya kehamilan meliputi perdarahan pervaginam, nyeri abdomen yang hebat, berkurangnya gerakan janin, bengkak, penglihatan kabur, sakit kepala hebat, demam, muntah-muntah hebat, keluar cairan pervaginam secara tiba-tiba? .

Berdasarkan hasil studi pendahuluan pada tanggal 24-25 April 2017, tercatat bahwa banyak ibu hamil yang memeriksakan kehamilannya di BPM Sumidyah. Hal tersebut dapat dilihat dari buku laporan ANC BPM Sumidyah yang menunjukkan rata-rata tiap bulannya BPM ini terdapat lebih dari 30 orang yang memeriksakan kehamilannya. Terhitung mulai tanggal 1-25 April 2017, terdapat ibu hamil yang memiliki faktor resiko kehamilan antara lain usia kurang dari 20 tahun atau lebih dari 35 tahun, abortus, tinggi badan kurang dari $145 \mathrm{~cm}$, anak lebih dari 4, dan riwayat kurang energi kronis (KEK) dengan LILA < 23,5 cm. Sedangkan berdasarkan laporan mulai bulan januari sampai april, ada juga faktor resiko lainnya antara lain post date, riwayat preeklampsia, riwayat SC ditambah infus, terlalu lama hamil ataupun terlalu dekat jarak persalinan terakhir dengan kehamilan ( $<2$ tahun), dan riwayat manual plasenta.

Faktor-faktor yang berhubungan dengan pengetahuan 
ibu tentang tanda bahaya kehamilan antara lain usia, pendidikan, pekerjaan, paritas, kunjungan ANC, dan dukungan suami. Ibu hamil yang berumur 20-35 tahun mem punyai kemampuan untuk mengenal tanda bahaya kehamilan 6 kali lebih baik dibandingkan dengan yang berusia $<20$ tahun atau $>35$ tahun). Hasil penelitian di Tanzania menunjukkan bahwa ibu hamil yang memiliki pendidikan menengah atau tinggi akan meningkatkan kesadaran tentang tanda bahaya dalam kehamilan sebesar 6 kali lipat dibandingkan dengan ibu hamil yang tidak berpendidikan". Lingkungan pekerjaan juga dapat menjadikan seseorang memperoleh pengetahuan yang bisa bersumber dari rekan kantor, sehingga seseorang yang bekerja akan mempunyai pengetahuan yang lebih baik daripada orang yang tidak bekerja. lbu hamil primipara memiliki pengetahuan yang kurang dibandingkan dengan ibu hamil mulltipara yang tentunya lebih banyak memiliki pengalaman dalam masa kehamilan. Kunjungan ANC yang kurang membuat ibu hamil tidak tahu resiko kehamilan sehingga pengetahuan ibu yang kurang tentang tanda bahaya kehamilan akan membuat ibu kurang waspada terhadap tanda bahaya kehamilan ${ }^{9}$. Selain itu, dukungan suami juga dapat mence gah keterlambatan mengenal tanda bahaya kehamilan karena suami mem punyai peranan yang penting dalam mendukung kesehatan ibu hamil ${ }^{10}$.

Tujuan dari penelitian yang dilakukan saat ini adalah mengidentifikasi dan menganalisis apakah ada hubungan karakteristik ibu dan dukungan suami dengan tingkat pengetahuan ibu hamil tentang tanda bahaya kehamilan di BPM Sumidyah Ipung. Penelitian ini diharapkan dapat menambah motivasi masyarakat khususnya para ibu untuk lebih aktif konsultasi kepada petugas kesehatan sehingga bisa mengambil sikap yang tepat untuk segera datang untuk memeriksakan konsisinya ke petugas kesehatan jika mengalami tan da bahaya kehamilan dan tidak terlam bat dalam penanganannya. Penelitian ini dapat menjadi bahan pertimbangan dalam menyusun program promosi kesehatan dalam pemberian informasi pelayanan program KIA yang baik kepada masyarakat terutama dalam masa kehamilan.

\section{METODE PENELITIAN}

\section{Rancangan / Desain Penelitian}

Pada penelitian ini menggunakan desain penelitian berupa observasional analitik dengan pendekatan cross sectional.

\section{Sumber Data}

Dalam penelitian ini digunakan data primer dari hasil pengisian lembar kuisioner yang berisi tentang tingkat pengetahuan tentang tanda bahaya kehamilan dan dukungan suami yang telah di uji validitas dan reliabilitas.

\section{Sasaran Penelitian}

Populasi dalam penelitian ini adalah semua ibu hamil yang memeriksakan kehamilannya di BPM Sumidyah pada bulan 29 Juli19 Agustus 2017. Jumlah sampelnya yang diperlukan dalam penelitian ini sebanyak 32 ibu hamil. 


\section{Pengembangan Instrumen dan Teknik Pengumpulan Data}

Variabel independen (bebas) pada penelitian ini adalah karakteristik ibu (usia, pendidikan, pekerjaan, paritas, riwayat kunjungan ANC) dan dukungan suami. Variabel dependen (terikat) pada penelitian ini adalah tingkat pengetahuan tentang tanda bahaya kehamilan.

Variabel usia terbagi menjadi dua kategori yaitu reproduksi sehat (20-35 tahun) dan reproduksi tidak sehat $(<20$ tahun atau $>35$ tahun). Variabel pendidikan dibagi menjadi dua kategori yaitu pendidikan rendah (tidak sekolah, SD, SMP) dan pendidikan tinggi (SMA, Akademi/PT). Variabel pekerjaan terbagi menjadi dua kategori yaitu bekerja dan tidak bekerja. Variabel paritas dibagi menjadi beberapa kategori antara lain nuliipara, primipara, multipara. Variabel riwayat kunjungan ANC terbagi menjadi riwayat kunjungan terpenuhi dan tidak terpenuhi. Variabel dukungan suami ada tiga kategori yaitu dukungan suami kurang, sedang dan baik. Variabel tingkat pengetahuan tentang tanda bahaya kehamilan ada tiga kategori yaitu kurang, cukup, dan baik.

Dalam penelitian ini mengguna kan teknik quota diberikan sesuai dengan kriteria insklusi dan eksklusi pada ibu hamil di BPM Sumidyah.

\section{Teknik Analisis Data}

Teknik analisa data mengguna kan uji statistik ChiSquare dengan derajat kepercayaan $95 \%$ dengan $\alpha=0,05$. Analisis data pada penelitian ini terdiri dari analisis univariat dan bivariat.
Analisis univariat digunakan untuk memberikan gambaran distribusi pada setiap variabel yaitu usia, pendidikan, pekerjaan, paritas, riwayat kunju ngan ANC, dukungan suami dan ting kat pengetahuan tentang tanda bahaya kehamilan. Setelah itu dilanjutkan de ngan analisis bivariat, digunakan untuk mengetahui hubungan atau korelasi antara dua variabel yang dihubungkan.

Penelitian ini telah mendapatkan persetujuan kelaikan etik dengan bukti nomor ethical clearance yang telah disetujui oleh komisi etik penelitian kesehatan Fakultas Kedokteran Univer sitas Brawijaya, dengan No. 254/ EC/ KEPK - S1 - KB/ 07/ 2017.

\section{HASIL PENELITIAN}

\section{Analisis Univariat}

\section{Distribusi Karakteristik Ibu berdasarkan Usia}

Berdasarkan

hasil

pengambilan data yang telah dilakukan, usia ibu dibagi menjadi 2 kategori, yaitu usia reproduksi tidak sehat dan usia reproduksi sehat. Persentase usia ibu dapat diamati pada tabel dibawah ini: :

Tabel 1. Distribusi Berdasarkan Usia

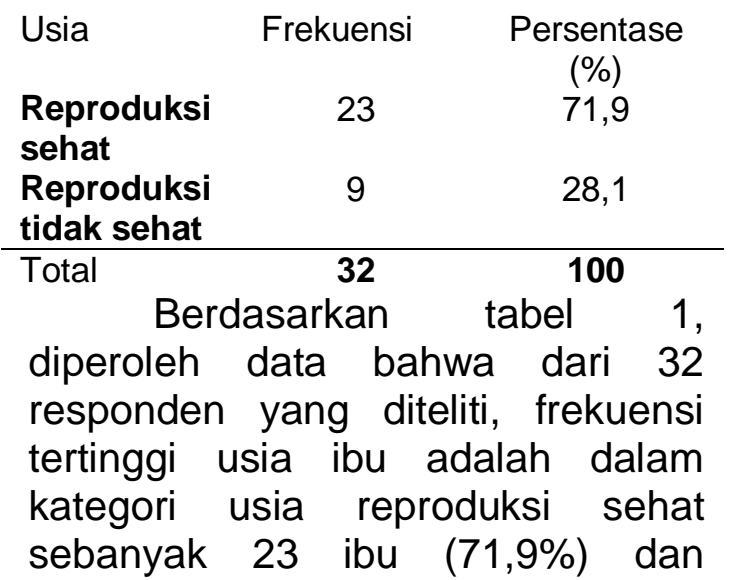


frekuensi terendah usia ibu adalah dalam kategori reproduksi tidak sehat sebanyak 9 ibu $(28,1 \%)$.

\section{Distribusi Karakteristik lbu berdasarkan Tingkat Pendidikan}

Berdasarkan

hasil

pengambilan data yang telah dilakukan, pendidikan ibu dikategorikan menjadi 2, yaitu pendidikan rendah dan pendidikan tinggi. Persentase pendidikan ibu dapat diamati pada tabel dibawah ini:

Tabel 2. Distribusi Berdasarkan Tingkat Pendidikan

Tingkat Frekuensi

Persentase

Pendidikan

Rendah 12

37,5

Tingg 20 62,5

Total 32 100

Berdasarkan tabel 2, diperoleh data frekuensi terbanyak yaitu pada tingkat pendidikan tinggi sebanyak 20 ibu (62,5\%) dan frekuensi terendah pada tingkat pendidikan rendah sebanyak 12 ibu $(37,5 \%)$.

\section{Distribusi Karakteristik lbu berdasarkan Pekerjaan}

Pekerjaan ibu dapat dikategorikan menjadi dua yaitu tidak bekerja dan bekerja. Persentase pekerjaan dijelaskan pada tabel berikut:

Tabel 3. Distribusi Berdasarkan Pekerjaan

\begin{tabular}{|c|c|c|}
\hline $\begin{array}{l}\text { Status } \\
\text { Pekerjaan } \\
\text { Bekerja }\end{array}$ & Frekuensi & $\begin{array}{c}\text { Persentase } \\
(\%) \\
43,8\end{array}$ \\
\hline $\begin{array}{l}\text { Tidak } \\
\text { Bekerja }\end{array}$ & 18 & 56,2 \\
\hline Total & 32 & 100 \\
\hline
\end{tabular}

adalah ibu tidak bekerja yaitu sebanyak 18 ibu (56,2\%). Sedangkan frekuensi pekerjaan yang paling sedikit yaitu ibu bekerja sebanyak 14 ibu $(43,8 \%)$.

\section{Distribusi Karakteristik lbu berdasarkan Paritas}

Paritas Frekuensi Persentase

\begin{tabular}{lcc} 
Nullipara & 13 & $(\%)$ \\
Primipara & 10 & 40,6 \\
Multipara & 9 & 31,2 \\
\hline Total & $\mathbf{3 2}$ & $\mathbf{1 0 0}$
\end{tabular}

Paritas ibu dalam penelitian ini dikategorikan menjadi 3 kategori yaitu nullipara, primipara, dan multipara. Persentase pada masingmasing paritas dijelaskan pada tabel berikut:

\section{Tabel 4. Distribusi Berdasarkan} Paritas

Berdasarkan tabel 4, jenis paritas dengan frekuensi tertinggi adalah ibu dengan paritas nullipara sejumlah 13 ibu (40,6\%) dan frekuensi terendah adalah ibu dengan paritas multipara sejumlah 9 ibu $(28,1 \%)$.

Distribusi Karakteristik Ibu berdasarkan Riwayat Kunjungan ANC

Berdasarkan
pengambilan data yang telah
dilakukan, riwayat kunjungan ANC
dibagi menjadi dua, yaitu terpenuhi
dan tidak terpenuhi.


Persentase riwayat kunjungan ANC dapat diamati pada tabel dibawah ini:

Tabel 5. Distribusi Berdasarkan

Tingkat Frekuensi Persentase

Pengetahuan (\%)

Kurang $\quad 10 \quad 31,2$

$\begin{array}{lll}\text { Cukup } & 8 & 25,0\end{array}$

Baik $14 \quad 43,8$

\begin{tabular}{|c|c|c|}
\hline Total & 32 & 100 \\
\hline
\end{tabular}

Riwayat Kunjungan ANC

Berdasarkan tabel

5.5

diperoleh data frekuensi riwayat

kunjungan ANC tertinggi yaitu pada

kategori terpenuhi sebanyak 28 ibu

$(87,5 \%)$. dan terendah yaitu pada kategori tidak terpenuhi sebanyak 4 ibu (12,5\%).

Tabel 6. Distribusi berdasarkan

Dukungan Frekuensi Persentase

Suami

Dukungan

Suami

$6 \quad 18,8$

Sedang

Dukungan

\begin{tabular}{lll} 
Suami Baik & 26 & 81,2 \\
\hline Total & $\mathbf{3 2}$ & $\mathbf{1 0 0}$
\end{tabular}

Dukungan Suami

Distribusi Dukungan Suami

Dukungan suami dalam

penelitian ini dikategorikan menjadi

dukungan suami sedang dan baik.

Persentase dukungan suami

dijelaskan pada tabel berikut:

Berdasarkan tabel 6

diperoleh data frekuensi dukungan suami tertinggi yaitu dukungan suami baik sebanyak 26 ibu $(81,2 \%)$

dan frekuensi terendah pada dukungan suami sedang sebanyak 6 ibu (18,8\%).

\section{Distribusi Tingkat Pengetahuan Ibu Hamil tentang Tanda Bahaya Kehamilan}

Tingkat pengetahuan dalam penelitian ini dibedakan menjadi tiga kategori yaitu kurang, cukup, baik. Persentase tingkat pengetahuan tentang tanda bahaya kehamilan yang telah dikelompokkan dapat diamati pada tabel berikut:

Tabel 7. Distribusi Berdasarkan Tingkat Pengetahuan tentang Tanda Bahaya Kehamilan

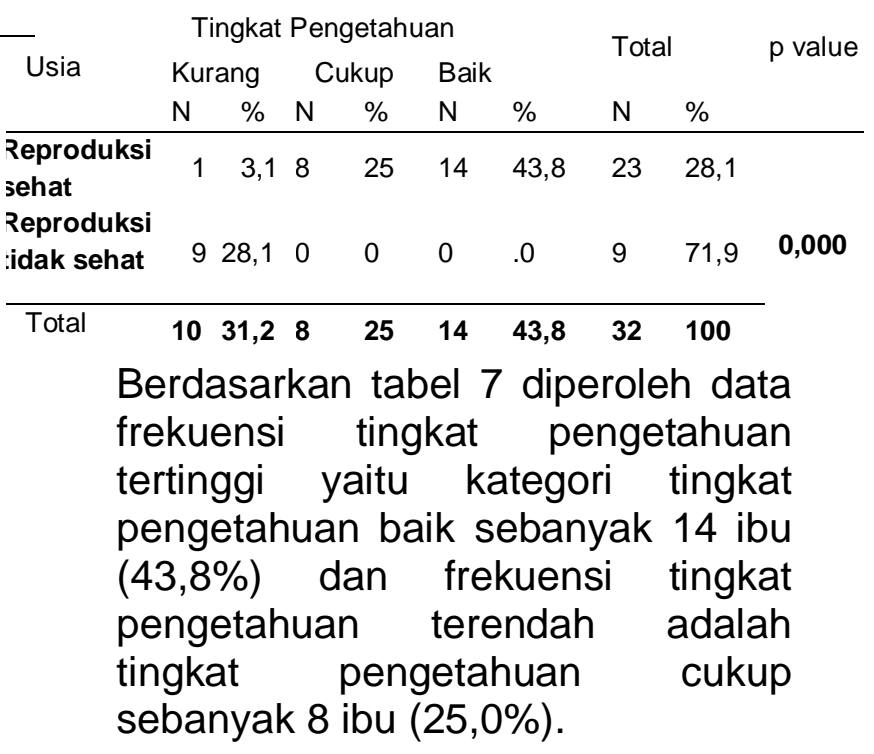

$\begin{array}{lcc}\begin{array}{l}\text { Riwayat } \\ \text { Kunjungan }\end{array} & \text { Frekuensi } & \begin{array}{c}\text { Persentase } \\ (\%)\end{array} \\ \begin{array}{l}\text { ANC } \\ \text { Terpenuhi }\end{array} & 28 & 87,5 \\ \text { Tidak } & 4 & 12,5 \\ \text { Terpenuhi } & \mathbf{3 2} & \mathbf{1 0 0}\end{array}$

Analisis Bivariat

Hubungan antara Usia Ibu dengan Tingkat Pengetahuan tentang Tanda Bahaya Kehamilan

Distribusi responden jika ditinjau dari tingkat pengetahuan berdasarkan usia adalah sebagai berikut: 
Tabel 8. Distribusi Tingkat Pengetahuan Berdasarkan Usia

Dari hasil analisis bivariat menunjukkan bahwa tingkat pengetahuan dengan frekuensi

\begin{tabular}{|c|c|c|c|c|c|c|c|c|c|}
\hline \multirow{2}{*}{$\begin{array}{l}\text { Pendidi } \\
\text { kan }\end{array}$} & \multicolumn{4}{|c|}{ Tingkat Pengetahuan } & \multicolumn{2}{|r|}{ Baik } & \multicolumn{2}{|c|}{ Total } & \multirow{2}{*}{$\begin{array}{c}P \\
\text { value }\end{array}$} \\
\hline & $\mathrm{N}$ & $\%$ & $\mathrm{~N}$ & $\%$ & $V$ & $\%$ & $\mathrm{~N}$ & $\%$ & \\
\hline \multirow{2}{*}{$\begin{array}{l}\text { Rendah } \\
\text { Tinggi }\end{array}$} & 7 & 21,9 & 2 & 6,2 & 3 & 9,4 & 12 & 37,5 & \\
\hline & & 9,4 & 6 & 18,8 & 1 & 34,4 & 20 & 62,5 & 0,037 \\
\hline
\end{tabular}

$\begin{array}{lllllllll}\text { Total } & 10 & 31,2 & 8 & 25,0 & 14 & 43,8 & 32 & 100,0\end{array}$

tertinggi adalah dengan hasil baik yaitu sebanyak 14 ibu (43,8\%), dan sebagian besar pada usia reproduksi sehat sebanyak 23 ibu $(28,1 \%)$. lbu yang memiliki pengetahuan yang baik lebih banyak ditemukan pada kelompok usia reproduksi sehat sebanyak 14 ibu (43,8\%). Hasil analisis data antara usia dengan tingkat pengetahuan menunjukkan $p$ value $=$ 0,000 yang menandakan $p$ value kurang dari 0,05. Hasil tersebut

\begin{tabular}{|c|c|c|c|c|c|c|c|c|}
\hline \multirow{3}{*}{$\begin{array}{l}\text { Pekerja } \\
\text { an }\end{array}$} & \multicolumn{5}{|c|}{ Tingkat Pengetahuan } & \multirow{2}{*}{\multicolumn{2}{|c|}{ Total }} & \multirow{3}{*}{$\begin{array}{l}p \\
\text { value }\end{array}$} \\
\hline & \multicolumn{2}{|c|}{ Kurang } & Cukup & \multicolumn{2}{|c|}{ Baik } & & & \\
\hline & $\mathrm{N}$ & $\%$ & N \% & $\mathrm{N}$ & $\%$ & $\mathrm{~N}$ & $\%$ & \\
\hline $\begin{array}{l}\text { Tidak } \\
\text { Bekerja }\end{array}$ & 9 & 28,1 & 412,5 & 5 & 15,9 & 18 & 56,2 & \\
\hline Bekerja & 1 & 3,1 & 412,5 & 9 & 28,1 & 14 & 43,8 & 0,028 \\
\hline Total & 10 & $\begin{array}{l}31,2 \\
\text { men } \\
\text { anta } \\
\text { pens } \\
\text { keha }\end{array}$ & $\begin{array}{l}\text { buktik } \\
\text { a us } \\
\text { etahua } \\
\text { milan. }\end{array}$ & 14 & hoc & 32 & $\begin{array}{l}\text { hubur } \\
\text { in tir } \\
\text { da ba }\end{array}$ & $\begin{array}{l}\text { gan } \\
\text { kat } \\
\text { aya }\end{array}$ \\
\hline
\end{tabular}

Hubungan antara Pendidikan lbu dengan Tingkat Pengetahuan tentang Tanda Bahaya Kehamilan Tabel 9. Distribusi Tingkat Pengetahuan Berdasarkan Pendidikan

Dari hasil analisis bivariat menunjukkan bahwa tingkat pengetahuan dengan frekuensi tertinggi adalah dengan hasil baik yaitu sebanyak 14 ibu (43,8\%), dan sebagian besar pendidikan adalah pendidikan tinggi sebanyak 20 ibu $(62,5 \%)$. Ibu yang memiliki pengetahuan yang baik lebih banyak ditemukan pada kelompok pendidikan tinggi sebanyak 11 ibu $(34,4 \%)$. Hasil uji statistik antara pendidikan dengan tingkat pengetahuan menunjukkan $p$ value $=$ 0,037 yang menandakan $p$ value kurang dari 0,05 . Hasil tersebut membuktikan bahwa ada hubungan antara pendidikan ibu dengan tingkat pengetahuan tentang tanda bahaya kehamilan.

\section{Hubungan antara Pekerjaan lbu dengan Tingkat Pengetahuan tentang Tanda Bahaya Kehamilan Tabel 1.0 Distribusi Tingkat Pengetahuan Berdasarkan Pekerjaan}

Dari hasil analisis bivariat menunjukkan bahwa tingkat pengetahuan dengan frekuensi tertinggi adalah dengan hasil baik yaitu sebanyak 14 ibu (43,8\%), dan sebagian besar tidak bekerja sebanyak 18 ibu (56,2\%). Ibu yang memiliki pengetahuan yang baik lebih banyak ditemukan pada kelompok ibu yang bekerja sebanyak 9 ibu $(28,1 \%)$. Hasil uji statistik antara pekerjaan dengan 
tingkat pengetahuan menunjukkan $\mathrm{p}$ value $=0,028$ yang menandakan $p$ value kurang dari 0,05. Hasil tersebut membuktikan bahwa ada hubungan antara pekerjaan ibu dengan tingkat pengetahuan

$\begin{array}{cccc}\text { Tingkat Pengetahuan } & \text { Total } & p \\ \text { value }\end{array}$
an ANC

$\begin{array}{lllllllll}\mathrm{N} & \% & \mathrm{~N} & \% & \mathrm{~N} & \% & \mathrm{~N} & \%\end{array}$

$\begin{array}{lllllllll}\text { Terpenu } & 6 & 18,8 & 8 & 25,0 & 14 & 43,8 & 28 & 87,5\end{array}$

hi

Tidak

$\begin{array}{lllllllll}\text { Terpen } & 4 & 12,5 & 0 & 0 & 0 & 0 & 4 & 12,5\end{array}$

uhi

Total

$10 \quad 31,2 \quad 8 \quad 25,0 \quad 14 \quad 43,8 \quad 32 \quad 100,0$ tentang tanda bahaya kehamilan.

Hubungan antara Paritas Ibu dengan Tingkat Pengetahuan tentang Tanda Bahaya Kehamilan Tabel 11. Distribusi Tingkat Pengetahuan Berdasarkan Paritas

Dari hasil analisis bivariat menunjukkan bahwa tingkat pengetahuan dengan frekuensi tertinggi adalah dengan hasil baik yaitu sebanyak 14 ibu (43,8\%), dan sebagian besar paritas yaitu nullipara sebanyak 13 ibu $(40,6 \%)$. lbu yang memiliki pengetahuan yang baik lebih banyak ditemukan pada kelompok ibu dengan primipara sebanyak 6 ibu (18,8\%). Hasil uji statistik antara paritas dengan tingkat pengetahuan menunjukkan $p$ value $=0,049$ yang menandakan $p$ value kurang dari 0,05 . Hasil tersebut membuktikan bahwa ada hubungan antara paritas ibu dengan tingkat pengetahuan tentang tanda bahaya kehamilan.
Hubungan antara Riwayat Kunjungan ANC dengan Tingkat Pengetahuan tentang Tanda Bahaya Kehamilan

Tabel 12. Distribusi Tingkat Pengetahuan Berdasarkan Riwayat Kunjungan ANC

Berdasarkan tabel diatas dapat diketahui bahwa tingkat pengetahuan dengan frekuensi tertinggi adalah dengan hasil baik yaitu sebanyak 14 ibu (43,8\%), dan sebagian besar riwayat kunjungan ANC terpenuhi sebanyak 28 ibu Tingkat Pengetahuan

\begin{tabular}{lcccccccccc} 
Paritas & \multicolumn{1}{c}{ Kurang } & \multicolumn{1}{c}{ Cukup } & \multicolumn{2}{c}{ Baik } & & Total & $p$ \\
& $\mathrm{~N}$ & $\%$ & $\mathrm{~N}$ & $\%$ & $\mathrm{~N}$ & $\%$ & $\mathrm{~N}$ & $\%$ & \\
& & & & & & & & & \\
\hline Nullipara & 3 & 9,4 & 5 & 15,6 & 5 & 15,6 & 13 & 40,6 & \\
Primipara & 1 & 3,1 & 3 & 9,4 & 6 & 18,8 & 10 & 31,2 & \\
& & & & & & & & & $\mathbf{0 , 0 4 9}$
\end{tabular}

$\begin{array}{lllllllll}\text { Multipara } & 6 & 18,8 & 0 & 0 & 3 & 9,4 & 9 & 28,1\end{array}$

\begin{tabular}{lllllllll}
\hline Total & 10 & 31,2 & 8 & 25,0 & 14 & 43,8 & 32 & 100,0
\end{tabular}

$(87,5 \%)$. lbu yang memiliki pengetahuan yang baik lebih banyak ditemukan pada kelompok ibu dengan riwayat kunjungan ANC terpenuhi sebanyak 14 ibu (43,8\%). Hasil uji statistik antara riwayat kunjungan ANC dengan tingkat pengetahuan menunjukkan nilai $p$ value $=0,007$ yang berarti signifikan karena $p$ value $<0,05$. Hal ini menunjukkan bahwa ada hubungan antara riwayat kunjungan ANC ibu dengan tingkat pengetahuan tentang tanda bahaya kehamilan.

Hubungan antara
Suami dengan $\begin{array}{r}\text { Duknan } \\ \text { Tingkat }\end{array}$
Pengetahuan tentang Tanda
Bahaya Kehamilan


Tabel 13. Distribusi Tingkat Pengetahuan Berdasarkan Dukungan Suami

Dari hasil analisis bivariat menunjukkan bahwa tingkat pengetahuan dengan frekuensi tertinggi adalah dengan hasil baik yaitu sebanyak 14 ibu (43,8\%), dan sebagian besar ibu memiliki dukungan suami yang baik yaitu sebanyak 26 ibu $(81,2 \%)$. Ibu yang memiliki pengetahuan yang baik lebih banyak ditemukan pada kelompok ibu yang memiliki dukungan suami baik sebanyak 14 ibu (43,8\%). Hasil uji statistik antara dukungan suami dengan tingkat pengetahuan menunjukkan $p$ value $=0,007$ yang menandakan $p$ value kurang dari 0,05. Hasil tersebut membuktikan bahwa ada hubungan antara dukungan suami dengan tingkat pengetahuan tentang tanda bahaya kehamilan.

\section{PEMBAHASAN}

\section{Hubungan antara Usia dengan Tingkat Pengetahuan tentang Tanda Bahaya Kehamilan}

Pada penelitian saat ini, karakteristik usia pada ibu hamil dibagi menjadi 2 kategori, yaitu usia reproduksi sehat (usia 20-35 tahun) dan usia reproduksi tidak sehat (usia $<20$ tahun atau $>35$ tahun). Hasil penelitian di BPM Sumidyah Ipung menunjukkan bahwa rata-rata usia ibu paling banyak dalam kategori usia reproduksi sehat sebanyak 23 orang $(71,9 \%)$. Usia dapat menstimulasi pena laran dan daya tangkap seseorang. Jika usia ibu semakin bertambah, maka penalaran dan daya tangkapnya akan semakin tumbuh dan berkembang. Hal tersebut merupakan hal positif jika banyak

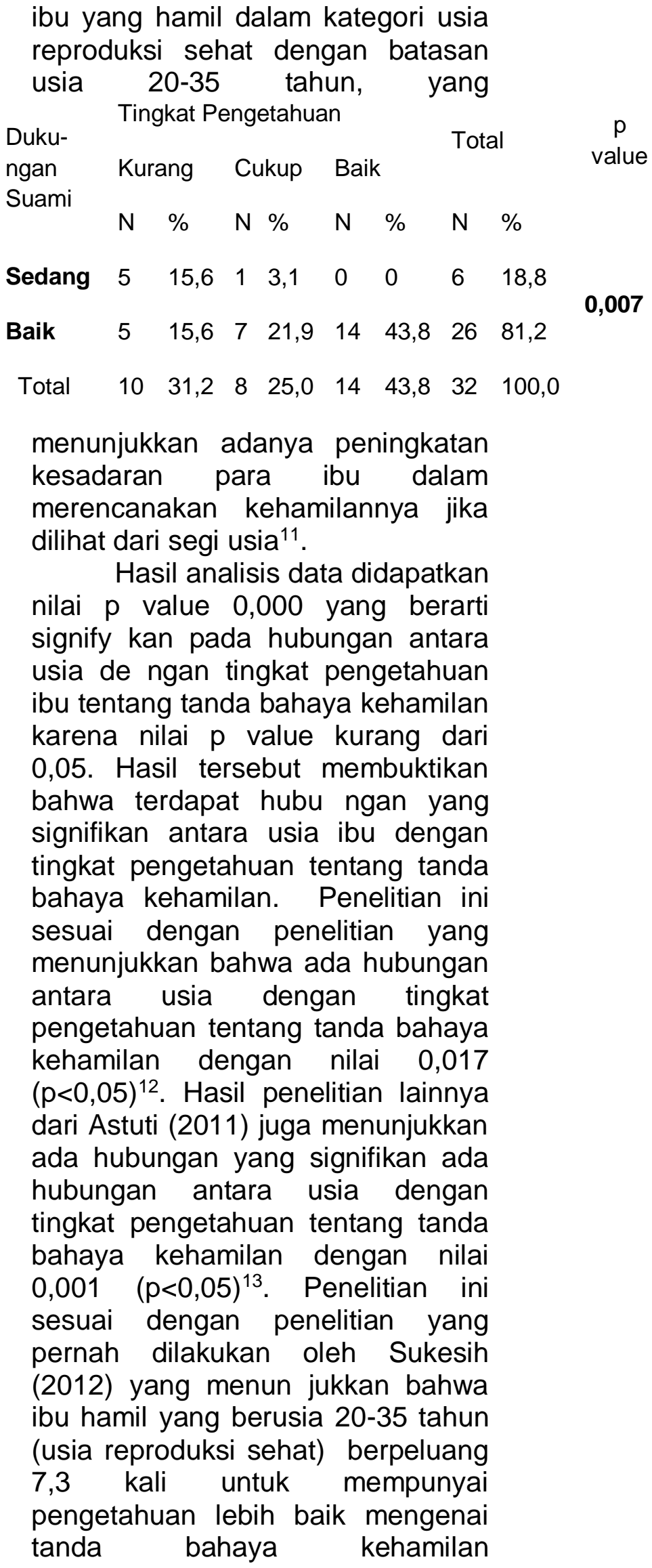


dibandingkan dengan yang berusia $<20$ tahun atau $>35$ tahun $^{14}$.

Semakin bertambah usia maka semakin bertambah pula daya tangkap dan pola pikirnya sehingga pengetahuan yang diperolehnya semakin baik. Namun beberapa teori berpendapat bahwa pada usia tertentu, kemampuan memahami dan menginngat pengetahuan akan berkurang. Beberapa teori ber pendapat tidak dapat mengajarkan kepandaian baru kepada orang yang sudah tua karena mengalami kemundu ran baik fisik maupun mental. Jadi dapat diperkirakan bahwa IQ akan menurun sejalan dengan bertambahnya usia ${ }^{1}$.

Seseorang yang hamil saat berusia masih muda mempunyai daya tangkap yang baik ketika memperoleh suatu informasi ataupun pengetahuan teraktual dan baru. Tetapi jika usianya kurang dari dua puluh tahun yang tergolong masih sangat muda mempunyai kesiapan yang kurang dalam mengatasi dan merawat dirinya sendiri ataupun janin yang dikandungnya sehingga seringkali terlalaikan penjagaan dalam menjalani masa kehamilannya ${ }^{14}$.

\section{Menurut}

Rogers,

menerangkan bahwa usia yang lebih muda mempu nyai kemampuan lebih cepat dalam menerima inovasi baru. Tetapi, usia yang terlalu muda ( $<20$ tahun) belum mempu nyai kesiapan secara fisik dan psikologis dalam menghadapi kehamilan, sehingga perawatan selama kehamilan sering terabaikan, karena tidak adanya keinginan untuk mencari pengetahuan mengenai kehamilannya. Sedangkan usia terlalu tua (> 35 tahun) bisa merasa bahwa dirinya telah terlatih dan mempunyai pengalaman yang lebih sehingga menjadikan ibu hamil tersebut kurang mempunyai kemauan dalam mendapatkan informasi-informasi yang baru seputar kehamilannya ${ }^{14}$. Disisi lain, seseorang yang usianya lebih dari 35 tahun akan mengalami penurunan kemampuan dalam menerima suatu informasi ataupun pengetahuan karena faktor semakin bertambahnya usia. Pada usia > 35 tahun, fungsi organ reproduksi mengalami penurunan sehingga dapat menambah resiko terjadinya kegawatdaruratan dan komplikasi seperti persalinan lama, perdarahan dan cacat bawaan ${ }^{12}$. Sehingga pada hasil penelitian ini sesuai dengan pernyataan bahwa usia dapat mempengaruhi daya tangkap dan pola pikir seseorang ${ }^{1}$.

\section{Hubungan antara Pendidikan dengan Tingkat Pengetahuan tentang Tanda Bahaya Kehamilan}

Pendidikan menggambarkan suatu usaha dalam meningkatkan atau pun memperbaiki potensi kemampuan dalam berpikir manusia untuk lebih bisa maju dan berkembang dalam menjalani kehidupan. Pada penelitian ini, pendidi kan dibagi menjadi dua kategori, yaitu pendidikan rendah dan pendidikan tinggi. Sebagian besar responden memiliki tingkat pendidikan tinggi sebanyak 20 orang $(62,5 \%)^{14}$.

Pendidikan merupakan suatu upaya meningkatkan sumber daya manusia berkualitas yang dapat mem pengaruhi orang lain baik individu, kelompok dan masyarakat. Tingginya tingkat pengetahuan akan mempe- ngaruhi upaya pencegahan dan kesadaran akan perlunya sikap untuk hidup sehat ${ }^{12}$. Pendidikan 
mempunyai kekuatan untuk mempengaruhi penalaran atau pola pikir seseorang sehingga dapat mendewasakan seseorang melalui suatu usaha dalam bentuk pelatihan ataupun pengajaran baik pada jenjang pendidikan formal ataupun informal. Untuk jenjang pendidikan formal bisa diartikan sebagai suatu bentuk penyampaian ilmu berupa materi yang diberikan oleh para pendidik kepada para anak didiknya. Pendidikan dapat mempengaruhi persepsi seseorang dalam mengambil keputusan dan bertindak ${ }^{14}$.

Dalam penelitian ini menunjukkan bahwa hasil uji statistik antara pendidikan dengan tingkat pengetahuan menunjukkan nilai $p$ value $=0,037$ yang berarti signifikan karena $p$ value $<0,05$. Hasil tersebut membuktikan bahwa ada hubungan antara pendidikan ibu dengan tingkat pengetahuan tentang tanda bahaya kehamilan. Penelitan ini sesuai dengan penelitian yang pernah dilakukan oleh Sulyani (2013) yang menunjukkan bahwa ada hubungan antara pendidikan dengan tingkat pengetahuan tentang tanda bahaya kehamilan dengan nilai 0,007 $(p<0,05)^{8}$. Hasil penelitian lainnya dari Astuti (2011) juga menunjukkan ada hubungan yang signifikan ada hubungan antara pendidikan dengan tingkat pengetahuan tentang tanda bahaya kehamilan dengan nilai $0,001 \quad(p<0,05)^{12}$. Penelitian lainnya juga memberikan kesimpulan bahwa ada hubungan antara pendidikan dengan tingkat pengetahuan tentang tanda bahaya kehamilan dengan nilai 0,015 $(p<0,05)^{15}$. Ibu hamil yang berpendidikan tinggi berpeluang 8,1 kali mempunyai pengetahuan lebih baik mengenai tanda bahaya kehamilan dibandingkan dengan ibu hamil yang berpengetahuan rendah ${ }^{14}$.

Pendidikan merupakan pemicu utama kemauan seorang ibu hamil untuk mencari tahu tentang tandatanda bahaya kehamilan ${ }^{23}$. Pendidikan akan berpengaruh terhadap cara berfikir dalam pengambilan keputusan seseorang untuk menggunakan pela yanan kesehatan, maka semakin tinggi pendidikan ibu akan semakin baik pula pengetahuan kesehatan. Tingkat pendi dikan yang tinggi mempunyai pengaruh yang baik dalam mempermudah ibu hamil untuk menerima informasi-infor masi yang baru karena bisa lebih cepat memahaminya. Semakin tinggi tingkat pendidikan maka diharapkan semakin baik pula pengetahuan ibu hamil dalam mengenal dan memahami tanda bahaya kehamilan. Ibu dan keluarga dapat lebih mudah mengenali tanda bahaya kehamilan yang muncul dan menerapkan respon yang cepat untuk segara ke tenaga kesehatan jika terjadi tanda bahaya kehamilan ${ }^{12}$. Sedangkan pendidikan rendah walaupun sudah ada sarana yang baik namun belum tentu dipergunakan, hal ini disebabkan seorang pendidikan rendah tidak peduli terhadap program kesehatan sehingga tidak mengenal bahaya yang mungkin terjadi ${ }^{15}$.

Tingkat pendidikan dapat mempengaruhi daya pikir seseorang untuk dapat menerima segala informasi dari lingkungan sekitarnya ${ }^{14}$. Pendidi kan yang tinggi atau baik dapat mem perluas ilmu pengetahuan ibu hamil. Ibu hamil yang berpendidikan tinggi mempunyai kepedulian yang lebih 
besar dalam menjaga kehamilannya terutama untuk mengetahui tanda bahaya kehamilan sebagai upaya mencegah timbulnya komplikasi dalam kehamilan. Sementara itu, jika seorang ibu hamil yang mempunyai pendidikan rendah maka dapat mengakibatkan terhambatnya atau kurangnya penge tahuan atau informasi yang bisa di peroleh pada tingkat pendidikan yang lebih tinggi ${ }^{12}$. Jadi, semakin tinggi pendidikan maka akan semakin mudah seseorang dalam menerima informasi sehingga lebih mudah untuk mening katkan pengetahuannya tentang tanda bahaya kehamilan ${ }^{14}$.

\section{Hubungan antara Pekerjaan dengan Tingkat Pengetahuan tentang Tanda Bahaya Kehamilan}

Bekerja merupakan aktivitas pokok yang dilakukan dengan rutin untuk menunjang kebutuhan rumah tangga. Status pekerjaan akan memudahkan untuk mendapatkan pelayanan kesehatan, ibu hamil tetap bekerja dan tidak merubah pola bekerja sehari-hari ${ }^{15}$. Untuk keperluan analisis data, pekerjaan dideskripsikan dengan kategori bekerja dan tidak bekerja. Pada penelitian saat ini membuktikan bahwa sebagian besar ibu hamil memilih untuk tidak bekerja yaitu sebanyak 18 ibu (56,2\%). Hal tersebut menjelaskan bahwa sebagian besar ibu hamil menjalani perannya secara penuh sebagai seorang istri yang mengurus segala keperluan rumah tangga dan sebagai ibu yang mengasuh dan mendidik anaknya. Dalam sebuah keluarga biasanya terdapat pembagian peranan,dimana seorang suami sebagai kepala keluarga mempunyai tugas mencari nafkah untuk kebutuhan hidup sehari-hari, sedangkan seorang istri sebagai pengurus segala keperluan rumah tangga dalam keluarganya ${ }^{12}$. Hasil uji statistik antara pekerjaan dengan tingkat pengetahuan menunjukkan nilai $p$ value $=0,028$ yang berarti signifikan karena $\mathrm{p}$ value $<0,05$. Hasil tersebut membuktikan bahwa ada hubungan antara pekerjaan ibu dengan tingkat pengetahuan tentang tanda bahaya kehamilan. Sebagian besar ibu hamil tidak bekerja artinya mereka mempunyai waktu yang cukup banyak yang dapat digunakan untuk mencari informasi seputar kehamilan sehingga pengetahuanya menjadi baik ${ }^{6}$.Namun, tidak semua ibu yang tidak bekerja mempunyai waktu luang untuk mendapatkan informasi. Hal ini mungkin dikarenakan ibu cenderung untuk mengurusi urusan rumah tangga. Selain itu, hal ini juga bergantung pada keinginan ibu untuk mendapatkan informasi tersebut ${ }^{3}$.

$$
\text { Wanita seringkali }
$$

meneruskan bekerja selama kehamilan. Jenis pe erjaan, tingkat aktivitas fisik, risiko lingkungan atau bahaya pekerjaan, dan masalah obstetri atau medis wanita mempengaruhi apakah dan berapa lama dia harus melanjutkan bekerja selama kehamilan. Jika tidak ada faktor risiko, kerja tidak meningkatkan komplikasi di akhir kehamilan, kelahiran prematur, atau kelahiran bayi berat lahir rendah ${ }^{9}$. Hal-hal yang perlu diperhatikan dalam pekerjaan atau aktivitas bagi ibu hamil adalah apakah aktivitasnya berisiko bagi kehamilan. Contoh aktivitas yang berisiko bagi ibu hamil adalah aktivitas yang meningkatkan stress, 
berdiri lama sepanjang hari, mengangkat sesuatu yang berat, paparan terhadap suhu atau kelembaban yang ekstrim tinggi atau rendah, pekerjaan dengan paparan radiasi ${ }^{14}$. Wanita menghadapi banyak tuntutan di rumah dan di tempat kerja yang dapat menciptakan konflik peran. Rata-rata wanita di seluruh dunia bekerja 80 jam setiap minggu di rumah dan di tempat kerja. Sedangkan rata-rata pria bekerja 50 jam setiap minggu ${ }^{9}$. Wanita yang dalam pekerjaannya perlu berdiri dalam waktu lama, berulangkali membungkuk dan menekuk, menaiki tanjakan atau tangga, dan mengangkat benda berat mengalami lebih banyak infark plasenta, abortus spontan, dan bayi lahir dengan berat badan rendah ${ }^{10}$.

Ibu hamil yang setiap harinya tidak sibuk dengan rutinitas pekerjaan mempunyai peluang lebih banyak untuk datang memeriksakan kehamilannya dan mendapatkan informasi tentang kesehatan seputar kehamilannya. Sementara itu, untuk ibu hamil yang bekerja diluar rumah seringkali tidak mempunyai lebih banyak waktu untuk memeriksakan kehamilan sehingga mempunyai pengetahuan yang kurang ${ }^{14}$.

\section{Hubungan antara Paritas dengan Tingkat Pengetahuan tentang Tanda Bahaya Kehamilan}

Paritas adalah jumlah kehamilan yang menghasilkan janin hidup, bukan jumlah janin yang dilahirkan. Janin yang lahir hidup ataupun mati tidak dapat mempengaruhi status paritas ${ }^{6}$. Paritas ibu dalam penelitian ini dikategorikan menjadi 3 kategori yaitu nullipara, primipara, dan multipara. Jenis paritas dengan frekuensi tertinggi adalah ibu dengan paritas nullipara sejumlah 13 ibu $(40,6 \%)^{14}$.

Pengetahuan

seseorang meru pakan hasil dari pengalaman, yaitu dipengaruhi oleh pengalaman sebelum nya dan oleh kebutuhan individu $^{12}$. Pengalaman pribadi seorang ibu dapat digunakan sebagai upaya dalam memperoleh suatu pengetahuan. Hal tersebut dapat dilakukan dengan cara mengulang kembali pengalaman yang pernah diperoleh atau dialaminya dalam memecahkan persoalan yang dihadapi dalam masa yang akan datang. Pengalaman dalam melewati masa kehamilan akan berdampak terhadap pola pikir atau pandangan, sikap dan tindakan ibu pada kehamilan berikutnya ${ }^{14}$.

Hasil uji statistik antara paritas dengan tingkat pengetahuan menunjukkan nilai $p$ value $=0,049$ yang berarti signifikan karena $p$ value $<0,05$. Hal ini menunjukkan bahwa ada hubungan antara paritas ibu dengan tingkat pengetahuan tentang tanda bahaya kehamilan. Penelitan ini sesuai dengan penelitian yang pernah dilakukan oleh Sulyani (2013) yang menunjukkan bahwa ada hubungan antara paritas dengan tingkat pengetahuan tentang tanda bahaya kehamilan dengan nilai 0,000 $(p<0,05)^{13}$. Hasil penelitian lainnya dari Astuti (2011) juga menunjukkan ada hubungan yang signifikan ada hubungan antara paritas dengan tingkat pengetahuan tentang tanda bahaya kehamilan dengan nilai $0,040(p<0,05)^{2}$.

Hal ini tidak sesuai dengan penelitian Sukesih (2012) di wilayah Puskesmas Tegal yang menunjukkan tidak ditemukan 
adanya hubungan yang bermakna antara pengalaman dengan pengetahuan ibu. Sholihah (2007) di Kabupaten Garut juga menunjukkan bahwa pengalaman mempunyai anak (paritas) tidak berhubungan dengan pengetahuan tentang tanda bahaya pada kehamilan ${ }^{12}$.

Hasil penelitian menunjukkan adanya paritas multipara yang memiliki tingkat pengetahuan kurang yaitu sebanyak 6 ibu $(18,8 \%)$. Hal tersebut bisa terjadi karena seiring dengan bertambahnya jumlah anak yang dimiliki oleh seorang ibu, maka akan semakin banyak juga waktu dan perhatian ibu yang tersita untuk mengurus, mendidik dan membesarkan anak-anaknya. Sehingga ibu tidak memiliki waktu yang cukup luang untuk menambah pengetahuan dan pada akhirnya akan berpengaruh pada sikap ataupun pengetahuan ibu dalam mengetahui tanda-tanda bahaya kehamilan. Hal tersebut berbeda dengan ibu yang belum memiliki anak yang pastinya mempunyai waktu dan kesempatan lebih banyak untuk menambah pengetahuan dan wawasannya mengenai tanda bahaya kehamilan sehingga diharapkan sikap dan pengetahuan ibu dalam mengenal tanda bahaya kehamilan semakin baik ${ }^{5}$.

\section{Hubungan antara Riwayat Kunjungan ANC dengan Tingkat Pengetahuan tentang Tanda Bahaya Kehamilan \\ ANC atau pemeriksaan} kehami lan merupakan pemeriksaan ibu hamil baik fisik dan mental serta menyelamatkan ibu dan anak dalam kehamilan, persalinan dan masa nifas, sehingga keadaan mereka post partum sehat dan normal ${ }^{17,24}$.
Kunjungan antenatal care adalah kunjungan ibu hamil ke bidan atau dokter sedini mungkin semenjak wanita merasa dirinya hamil untuk mendapatkan pelayanan/asuhan antenatal $^{7,14}$. Pada kunjungan ANC, pelayanan terhadap individu bersifat preventif care untuk mencegah terjadinya masalah yang kurang baik bagi ibu maupun janin. ANC merupakan upaya kesehatan perorangan yang memperhatikan ketelitian dan kualitas pelayanan medis yang diberikan, agar dapat melalui persalinan dengan sehat dan aman diperlukan kesiapan fisik dan mental ibu, sehingga ibu dalam keadaan status kesehatan yang optimal ${ }^{14}$.

Dalam penelitian ini yang dimaksud dengan riwayat kunjungan ANC adalah riwayat kunjungan ibu saat hamil dengan tenaga kesehatan untuk mendapatkan pelayanan ANC. Riwayat kunjungan ANC dinilai berdasarkan pertanyaan dalam kuesioner dan catatan buku KIA ibu. Kunjungan ANC dinilai baik apabila berjumlah minimal 4 kali selama kehamilan (1 kali pada TM 1, 1 kali pada TM 2, 2 kali pada TM 3). Riwayat kunjungan ANC dibagi menjadi dua, yaitu terpenuhi dan tidak terpenuhi. Frekuensi riwayat kunjungan ANC tertinggi yaitu pada kategori terpenuhi sebanyak 28 ibu $(87,5 \%)$. Hasil uji statistik antara riwayat kunjungan ANC dengan tingkat pengetahuan menunjukkan nilai $p$ value $=0,007$ yang berarti signifikan karena $p$ value $<0,05$. Hal ini menunjukkan bahwa ada hubungan antara riwayat kunjungan ANC ibu dengan tingkat pengetahuan tentang tanda bahaya kehamilan. Didalam kunjungan ANC terdapat konseling, sehingga dapat 
digunakan untuk memberikan informasi mengenati tanda bahaya kehamilan pada setiap kunjungan ANC. Semakin sering ibu hamil mendapatkan informasi maka akan semakin meningkat pengetahuan ibu hamil mengenai tanda bahaya kehamilan ${ }^{1}$.

Hal tersebut sesuai dengan penelitian yang dilakukan oleh Kartika (2012) yang menunjukkan hasil ada hubungan yang signifikan antara pengetahuan ibu hamil tentang tanda bahaya kehamilan dengan kepatuhan melakukan ANC dengan nilai $0,005 \quad(p<0,05)^{7}$. Penelitian ini juga sejalan dengan penelitian Sembiring (2013) dan Kamidah (2013) yang menghasilkan bahwa ada hubungan antara kepatuhan kunjungan ANC dengan tingkat pengetahuan ibu hamil tentang tanda bahaya kehamilan ${ }^{6,10}$. Semakin terpenuhi riwayat kunjungan ANC maka semakin baik pula tingkat pengetahuan? Sehingga kemungkinan ibu hamil untuk patuh melakukan kunjungan ANC akan semakin besar. Ibu hamil akan semakin ingin memeriksakan kehamilannya secara teratur atau patuh kepada petugas kesehatan khususnya bidan selam periode kehamilannya ${ }^{10}$.

$$
\text { Pemeriksaan kehamilan }
$$

(ANC) ini merupakan salah satu program yang terencana berupa observasi, edukasi, dan penanganan medik pada ibu hamil untuk memperoleh suatu proses kehamilan dan persalinan yang aman dan memuaskan. Tujuan utamanya adalah menurunkan atau mencegah kesakitan dan kematian maternal dan perinatal. Tujuan tersebut akan tercapai apabila ibu hamil patuh dalam melakukan pemeriksaan kehamilan. Secara deskriptif, penelitian ini menggambarkan bahwa ibu hamil yang sebagian besar dikategorikan patuh dalam melaksanakan kunjungan ANC sebanding dengan pengetahuan mereka yang sebagian besar dikategorikan baik ${ }^{6}$. Ibu hamil yang tidak memeriksakan kehamilannya secara teratur menyebabkan tidak terdeteksinya tanda bahaya dan komplikasi yang terjadi pada saat hamil atau pada saat persalinan yang akan mengancam kesehatan dirinya dan janin yang dikandungnya ${ }^{14}$. Dampak dari ketidakpatuhan ibu dalam kunjungan ANC adalah ibu hamil akan kurang mendapatkan informasi tentang cara perawatan kehamilan yang benar, tidak terdeteksinya penyakit dan komplikasi selama kehamilan. Sehingga apabila tidak ditangani akan mengakibatkan komplikasi pada saat kehamilan ataupun persalinan dan akan mengarah pada kematian ibu ${ }^{7}$.

\section{Hubungan antara Dukungan Suami dengan Tingkat Pengetahuan tentang Tanda Bahaya Kehamilan}

Dukungan suami pada saat kehamilan adalah segala sesuatu yang diperbuat suami dalam merespon kehamilan istrinya ${ }^{11}$. Dukungan suami menghasilkan suatu peranan yang penting dalam kesehatan selama masa kehamilan karena memberikan suatu hubungan ataupun dukungan sosial yang baik untuk meningkatkan kesehatan ibu hamil ${ }^{12}$.

Dukungan suami pada saat kehamilan adalah segala sesuatu yang diperbuat suami dalam merespon kehamilan istrinya dalam bentuk interaksi dimana ada 
hubungan saling mengasihi dan mendapatkan bantuan yang nyata dilakukan oleh seorang suami terhadap istrinya. Suami merupakan orang yang paling dekat dengan ibu dan memiliki banyak peran selama ibu menjalani masa kehamilan, persalinan, sampai nifas. Respon suami yang baik terhadap kehamilan istrinya merupakan sebuah perilaku positif yang dapat menyebabkan adanya rasa percaya diri, ketenangan batin dan pikiran positif. Wanita yang dijaga, diperhatikan, dilindungi,dan dikasihi oleh suaminya selama hamil akan mempunyai emosional yang stabil, kemungkinan terjadinya komplikasi persalinan berkurang, dan lebih mudah beradaptasi ${ }^{12}$.

Suami dapat memberikan dukungan dengan mengerti dan memahami setiap perubahan yang terjadi pada istrinya, memberikan perhatian dengan penuh kasih sayang dan berusaha untuk meringankan beban kerja istri. Dukungan suami yang didapatkan calon ibu akan menimbulkan perasaan tenang, sikap positif terhadap diri sendiri dan kehamilannya, maka diharapkan ibu dapat menjaga kehamilannya dengan baik sampai saat persalinan ${ }^{11}$.

Data frekuensi dukungan suami tertinggi yaitu dukungan suami baik sebanyak 26 ibu $(81,2 \%)$ dan frekuensi terendah pada dukungan suami sedang sebanyak 6 ibu (18.8\%). Dukungan suami masuk didalam lingkup dukungan sosial, dimana yang dimaksud dari dukungan sosial adalah bentuk dukungan dan hubungan yang baik untuk memberikan kontribusi penting pada kesehatan. Hal tersebut akan membuat orang merasa diperhatikan, dicintai, dimuliakan dan dihargai ${ }^{4}$.

Hasil uji statistik antara dukungan suami dengan tingkat pengetahuan menunjukkan nilai $p$ value $=0,007$ yang berarti signifikan karena $p$ value $<0,05$. Hal ini menunjukkan bahwa ada hubungan antara dukungan suami dengan tingkat pengetahuan tentang tanda bahaya kehamilan. Respon suami terhadap kehamilan istri yang dapat menyebabkan adanya ketenangan batin dan perasaan senang dalam istri. Wanita yang diperhatikan dan dikasihi oleh pasangan prianya selama hamil akan menunjukkan lebih sedikit gejala emosi dan fisik, lebih sedikit komplikasi persalinan, dan lebih mudah melakukan penyesuaian selama nifas ${ }^{11}$.

Adanya dukungan atau motivasi dari suami berperan sangat besar dalam menentukan status kesehatan dan tingkat pengetahuan ibu dalam mengetahui tanda-tanda bahaya kehamilan. Jika suami mengharapkan adanya kehamilan, maka akan memperlihatkan dukungannya dalam berbagai hal yang dapat mempengaruhi ibu menjadi lebih percaya diri, lebih berbahagia, menunjukkan kesiapan dan lebih kuat secara mental untuk menghadapi segala hal selama masa kehamilan tersebut. Keterlibatan anggota keluarga atau orang terdekat terutama pasangan/suami dapat membantu terjadinya perubahan untuk berperilaku dan juga meningkatkan kesadaran untuk berubah ke arah hidup sehat. Oleh karena itu, suami memiliki peranan yang sangat penting untuk memberikan berbagai jenis dukungan pada ibu supaya ibu merasa lebih nyaman dalam menjalani masa kehamilan dan 
meminimalkan resiko timbulnya tanda-tanda bahaya kehamilan ${ }^{15}$.

Suami dapat memberikan dukungan dengan mengerti dan memahami setiap perubahan yang terjadi pada istrinya, memberikan perhatian dengan penuh kasih sayang dan berusaha untuk meringankan beban kerja istri. Dukungan suami yang didapatkan calon ibu akan menimbulkan perasaan tenang, sikap positif terhadap diri sendiri dan kehamilannya, maka diharapkan ibu dapat menjaga kehamilannya dengan baik sampai saat persalinan ${ }^{16}$.

\section{SIMPULAN}

Pada karakteristik ibu, sebagian besar usia ibu dalam kategori usia reproduksi sehat sebanyak 23 ibu $(71,9 \%)$, sebagian besar mempunyai tingkat pendidikan yang tinggi sebanyak 20 ibu $(62,5 \%)$, sebagian besar ibu tidak bekerja yaitu sebanyak $18 \mathrm{ibu}$ $(56,2 \%)$, paritas paling banyak pada paritas nullipara sejumlah 13 ibu $(40,6 \%)$, dan riwayat kunjungan ANC tertinggi yaitu pada kategori terpenuhi sebanyak 28 ibu (87,5\%). Sebagian besar ibu memiliki dukungan suami yang baik sebanyak 26 ibu $(81,2 \%)$. Sebagian besar ibu memiliki kategori tingkat pengetahuan baik sebanyak 14 ibu $(43,8 \%)$.

Terdapat hubungan antara usia $(0,000 ; p<0,05)$, pendidikan $(0,037 ; p<0,05)$, pekerjaan $(0,028$; $p<0,05)$, paritas $(0,049 ; p<0,05)$, riwayat kunjungan ANC $(0,007$; $\mathrm{p}<0,05) \quad$ dengan tingkat pengetahuan ibu tentang tanda bahaya kehamilan. Serta terdapat hubungan antara dukungan suami dengan tingkat pengetahuan tentang tanda bahaya kehamilan dengan $p$ value $0,007(p<0,05)$.

\section{DAFTAR PUSTAKA}

\section{REFERENSI}

1. Kemenkes. 2014. Peningkatan Kesehatan Ibu dan Anak. Jakarta: Pusat Promosi Kesehatan Kementerian Kesehatan Republik Indonesia. http://promkes. depkes.go.id/dl/lembar\%20balik\%2 0poskesdes.pdf.

2. Kemenkes. $2014 . \quad$ Situasi Kesehatan Ibu. Jakarta: Pusat Data dan Informasi - Kementerian Kesehatan Republik Indonesia. http://www.depkes.go.id/ folder/view/01/structure-publikasipusdatin-info-datin.html

3. Kemenkes. 2010. Pedoman Pelayanan Antenatal Terpadu. Jakarta: Direktorat Jenderal Bina Kesehatan Masyarakat Kementerian Kesehatan Republik Indonesia.

http://perpustakaan.depkes.go.id:81 80/bitstream//123456789/202 4/2/BK2010-456.pdf

4. Kemenkes. 2010. Pedoman Pemantauan Wilayah Setempat Kesehatan Ibu Dan Anak (PWS$K I A)$. Jakarta: Direktorat Jenderal Bina Kesehatan Masyarakat \& Direktorat Bina Kesehatan lbu Kementerian Kesehatan Republik Indonesia.

http://www.gizikia.depkes.go.id/wpcontent/uploads/downloads/2013/08 IPedo man-PWS-KIA.pdf.

5. Kemenkes. 2013. Buku Saku Pelayanan Kesehatan lbu di Fasilitas Kesehatan Dasar dan Rujukan. Jakarta: Kementerian Kesehatan Republik Indonesia. http://www.gizikia.depkes.go.id/wpcontent/uploads/downloads/2013/12 /Buku -Saku-Pelayanan-Kesehatanlbu.pdf 
6. Kemenkes. 2013. Profil Kesehatan Indonesia $2012 . \quad$ Jakarta: Kementerian Kesehatan Republik Indonesia.

http://www.depkes.go.id/resources/ download/ pusdatin/profilkesehatan-indonesia/profilkesehatan-indonesia-2012.pdf

7. Agustini, S. 2012. Pengetahuan Ibu Hamil tentang Tanda-Tanda Bahaya Kehamilan di Wilayah Kerja UPT Puskesmas Cimandala Kecamatan Sukaraja Kabupaten Bogor Tahun 2012. Skripsi. Diterbitkan, Fakultas Kesehatan Masyarakat Universitas Indonesia, Depok.

lib.ui.ac.id/file?file=digital/20314706 -S Sri\%20Agustini.pdf

8. Pembe, Andrea B., Urasso, D.P., Carlsted, A., Lindmark, G., Nystrapq, L., Darj. 2011. Rural Tanzanian Women's Awarness of DANGER Sign of Obstetric Complication. Basic data Proquest health and medicine complete

9. Kartika, E.Y. 2012. Hubungan Pengetahuan lbu Hamil Trimester III tentang Tanda Bahaya Kehamilan dengan Kepatuhan ANC di wilayah Kerja Puskesmas Lerep Kecamatan Ungaran. Semarang: Akademi Kebidanan Ngudi Waluyo

10. Meko, M.Y.D. 2012. Faktor-Faktor yang Berhubungan dengan Pengetahuan Suami tentang Tanda Bahaya pada Masa Kehamilan, Persalinan dan Nifas di Wilayah Kerja Puskesmas Bakunase tahun 2011. Kupang: FKM Undana

11. Widiantari, N.K.N. 2015. Hubungan Karakteristik lbu dan Dukungan Sosial Suami Dengan Partisipasi Ibu Mengi kuti Kelas Ibu Hamil Di Kota Denpasar. Tesis. Diterbitkan, Magister IImu Kesehatan Masyarakat, Universitas Udayana, Denpasar. http://www.pps. unud.ac.id/thesis/pdf thesis/unud-

152 3-77867673tesis\%20\%20nopi\%20\% 20fix.pdf
12. Sulyani, P. 2013. Hubungan Karakte ristik lbu Hamil dengan Pengetahuan Ibu Hamil terhadap Tanda-Tanda Bahaya Kehamilan di Puskesmas Bandar Kabupaten Bener Meriah. Banda Aceh: Stikes Ubudiyah

13. Astuti, H.P. 2011. Hubungan Karakteristik lbu Hamil dengan Tingkat Pengetahuan tentang Tanda Bahaya pada Kehamilan di Puskesmas Sidoharjo Kabupaten Sragen. Jurnal Stikes Kusuma Husada Surakarta, hal. 1-13. http://digilib.stikeskusumahusa da.ac.id/files/disk1/3/01-gdltriwulanda - 119-1-tri wula-i.pdf

14. Sukesih. 2012. Faktor-Faktor yang Berhubungan dengan Pengetahuan Ibu Hamil Mengenai Tanda Bahaya dalam Kehamilan di Puskesmas Tegal Selatan Kota Tegal Tahun 2012. Skripsi. Diterbitkan, Fakultas Keseha tan Masyarakat Universitas Indonesia, lib.ui.ac.id/file?file=digital/203 15113-S Sri\%20Sukesih.pdf

15. Wulandari, R. 2014. Hubungan Tingkat Pendidikan Ibu Hamil dengan Pengetahuan Tanda Bahaya Kehami lan pada Trimester III di RB Harapan Bunda Surakarta. Surakarta: STIK PKU Muhammadiyah. http://digilib. stikespku.ac. id/ download.php?id=76.

16. 